\title{
MARKETING CHANNEL STRATEGY AND THE EFFECT OF CANNIBALIZATION ON RETAILING: A CONCEPTUAL OVERVIEW FROM MARKETING AND SUPPLY CHAIN PERSPECTIVE
}

\author{
Asst. Prof. Işık Özge YUMURTACI* \\ Dr.Gülmüş BÖRÜHAN** \\ Dr. Pervin ERSOY ${ }^{* * *}$
}

\begin{abstract}
The impressive growth of internet, globalization and diffusion of technology have impacted every industry and business model. Multichannel strategy of retailers should provide competitive advantage to cope with changing dynamics of globalized world. However, multichannel strategies can lead to disadvantageous outcomes such as cannibalization. Cannibalization refers to a firm losing market share due to the introduction of multichannel. The existing literature on cannibalization which is caused by multichannel strategies is controversial and the concept needs to be examined from different perspectives. In this study, it is aimed to develop a conceptual framework in case cannibalization effect occurs. To overcome the disadvantages of cannibalization, a theoretical approach based on the integration of marketing and supply chain perspectives, is proposed. Additionally, research propositions are provided for further research.
\end{abstract}

Keywords: cannibalization, retailing, marketing channels, supply chain

JEL Classification: M10, M31, L81

\section{PERAKENDECILIKTE PAZARLAMA KANALI STRATEJISİ VE YAMYAMLIK ETKİSI: \\ PAZARLAMA VE TEDARIKK ZINCIRİ BAKIŞ AÇISIYLA KAVRAMSAL BİR DEĞERLENDİRME}

$\ddot{\mathbf{O Z}}$

Internetin etkileyici gelişimi, küreselleşme ve teknolojinin yayllımı her sanayi ve iş modelini etkilemiştir.Çoklu kanal stratejisi küreselleşen dünyanın değişen dinamikleri ile başa çıkmak için perakendecilere rekabet avantajı sağlamalıdır. Ancak, çoklu kanal stratejileri, yamyamlık gibi dezavantajlı sonuçlara yol açabilir. Yamyamlık, birden fazla dağıtım kanalına girişs nedeniyle, firmanın Pazar payı kaybetmesi anlamına gelir. Çoklu kanal stratejileri nedeniyle mevcut yamyamlı

\footnotetext{
'̇zmir University of Economics, Faculty of Business, Department of Logistics Management, isik.yumurtaci@ieu.edu.tr

${ }^{* *}$ Yaşar University, Faculty of Economics and Administrative Sciences, International Logistics Department, gulmus.boruhan@yasar.edu.tr

${ }^{* * *}$ Yaşar University, Faculty of Economics and Administrative Sciences, International Logistics Department, pervin.ersoy@yasar.edu.tr
} 
literature tartışmalıdır ve kavramın farklı bakış açılarından incelenmesi gereklidir. Bu çalışmada, yamyamlık etkisi ortaya çıtı̆ı̆ında, yamyamlık etkisinin dezavantajlarını ortadan kaldırmak için teorik temele dayalı pazarlama ve tedarik zinciri bakış açısını bütünleştirerek bir kavramsal çerçeve sunulması amaçlanmaktadır. Ayrıca, gelecek araştırmalar için araştırma önerileri de sunulmuştur.

Anahtar Kelimeler: yamyamlık, perakendecilik, pazarlama kanalları, tedarik zinciri

JEL Sinıflandirmasi: M10, M31, L81

\section{INTRODUCTION}

Intensive and easy internet access have altered shopping behaviors of customers and retailers (Narwal and Sachdeva, 2013). There are projected to be 3.2 billion internet users by the end of 2015 (ITU, 2015). Advances in internet have removed barriers to entry in retailing, initiating movement towards multichannel retailing (Dholakia et al. 2005). Multichannel retailing entails the parallel use of several sales channels by retailing enterprises (Schramm-Klein, 2003) due to the unique benefits provided by each channel (Levy and Weitz, 2001)

Traditional retailers that have evolved into multichannel retailing currently dominate the internet retailing space (Kilcourse and Rowen 2008). Retailers have integrated electronic activities to their business strategies with the increasing importance of online sales in retailing (Kollmannet.al., 2012). According to the e-Marketer, total sales of e-retailing is $\$ 1.251$ trillion, and is expected to increase to $\$ 2.357$ trillion by 2017 (E-Marketer, 2014). Of the 50 largest e-retailers $75 \%$ are among the World's Top 250 Largest Retailers (Deloitte, 2014). These indicators show the growth of both online markets and competition worldwide.

Today, the need for multiple channel strategy by retailers is evident. Although multichannel retailing provides many advantages to the retailers, it may be challenging to create synergy across channels. The opportunities for multichannel retailers arise from their abilities to develop coherent channel strategies (Zhang et.al.,2010).

Multiple channel strategy is customer oriented, and aims to enhance customer loyalty (Wallace et al., 2004; Payne and Frow, 2005). Multiple channel strategy necessitates relationship management among channel members through supply chain management (Cooper and Lambert, 1997; Mentzer et al., 2001). Firms which are not capable of managing marketing channels may encounter with negative outcomes such as cannibalization (Webb,2002). It is observed that primary consideration in deciding whether firms should pursue multichannel strategies is the issue of "cross-channel cannibalization versus synergy" (Neslin and Shankar, 2009). Considering that retailing is amongst the most diverse and dynamic industries, managing different channels simultaneously is a complex process (George et al., 2013). 
Therefore, understanding and overcoming cannibalization need marketing and supply chain perspectives. Hence, we present a novel conceptual framework to deal with cannibalization. In line with the aims of the study, it consists of the following sections; the evolution of marketing channels in retailing, theoretical background on cannibalization, conceptual framework and research propositions, conclusion and further research.

\section{THE EVOLUTION OF MARKETING CHANNELS IN RETAILING}

Marketing channels are sets of interdependent organizations concentrated on the process of making a product available to the end-user (Kumar et al., 1995), serving downstream relationships linking the firm to the end customer (Kozlenkova et al., 2015). Marketing channel systems serve for marketing channels for the exchange of goods, money and information (Ehrens and Zapf, 1999).

Today, marketing channels and e-commerce benefit from advances in information technology. In the long-run, pure play internet retailers would have competitive advantage over traditional retailers regarding prices and range of products and/or services (Zhang et al. 2010). Due to the advances in information technology and internet penetration, customers have started to use the online channel, or use multiple channels, due to their lower costs compared to offline channels (Wolk and Skiera, 2009).

Multichannel retailers are the retailers that sell merchandise or services through more than one channel (Levy and Weitz, 2001). There are two types of the multiple channels; traditional retailers with the online channel added to their portfolio, and "pure-play" internet retailers, which open physical stores or collaborate with traditional retailers to sell their products (Agatz et. al., 2008). The majority of the world's top 50 e-retailers (42 e-retailers) are multichannel retailers (Deloitte, 2014).

Firms adding internet channels to existing channels aim to enhance performance, increase market penetration rate and decrease distribution costs (Geyskens et. al., 2002; Sharma, et. al. 2010). However, multichannel strategy may not be beneficial for the company performance; it is not easy to take full advantage of the internet channel (Wolk and Skiera, 2009). For instance, e-retailing can cause internet disintermediation. Internet disintermediation occurs when traditional channel partners are replaced with the e-retailers (Sharma and Gassenheimer, 2009), Thus, it can be disadvantageous, because manufacturers that disintermediate reseller channel partners by going online can lose support from traditional channel partners, or even their distribution network (Frazier, 1999). However, physical stores still retain their important role in online purchases, such that two-thirds of customers purchasing from online store visit a physical store before or after the purchasing transaction (AtKearney, 2014).

Many customers use online stores to compare alternative products, brands, prices and availability before shopping. Global retailers such as Wal-Mart and Dell use e-commerce websites to support their brick and mortar stores (Avery et. al., 2012). 
Multichannel retailing is useful for obtaining value from the internet, cross shopping opportunities for consumers, adjusting prices and providing long-term loyalty (Dholakia et. al., 2005). A multiple channel strategy creates synergy through physical stores acting as billboards for the brands, catalogs increasing product profile, and the internet as a storefront for online shopping (Avery et. al., 2012). However, using multiple channel strategy also presents difficulties for companies (Rosenbloom, 2007). Retailers need to consider other aspects, such as cross-channel integration. Cao and $\mathrm{Li}$ (2015:200) define cross-channel integration as "the degree to which a firm coordinates the objectives, design, and deployment of its channels to create synergies for the firm and offer particular benefits to its consumers." Hence, management of cross-channel integration can increase the likelihood of cannibalization (Tang and Xing, 2001).

Online channel is certainly a valuable resource for customers for providing information, and hence reducing search costs (Agatz, et. al., 2008). It serves to customers by providing additional information and increasing the sales network, thus leading to a competitive advantage and increased customer loyalty (Kollman et.al, 2012). Online channels potentially cannibalize the sales of traditional channels (Porter, 2001).

\section{THEORETICAL BACKGROUND ON CANNIBALIZATION}

The evolution of marketing channels in retailing and cannibalization are examined to provide grounding for the conceptual framework and propositions. Marketing channels are a set of interdependent organizations, the linkages among which are characterized by certain relationship mechanisms. Decisions on channel strategy involve channel members (physical and/or online). While cannibalization is a concept that needs to evaluate from multiple perspectives, it's important that retailers decide on their channel members, and manage relationships along the channel. Therefore the study draws on theories presuming resource and relationship management principles.

As a leading player, retailers have significant roles both in marketing channels and supply chains. To pursue these roles, retailers need certain inputs for performing their business activities. In a competitive environment, resources and capabilities become easily accessible to each competitor in a particular market (Skjoett-Larsen, 1999). Resources management, competition analysis and interaction between channel/chain members are mentioned in different theories.

Resource based theory (RBT) highlights the significance of resources management. The basic premise of RBT is discussed by Mahoney (1995:95) as follows: "A firm should select the strategy that takes into account the relationship between its resources and environmental opportunities in the generation of rents (defined as "the return in excess of a resource owner's alternative use costs". Regarding resources point of view, Resource Dependence Model (theory) considers firms' dependence on inputs (resources) for production and survival in the market and the role of relationship management in managing resources (Pfeffer and Salancik, 1978). 
RBT takes into account the internal analysis by focusing on resources and capabilities together with the external analysis based on analyzing competitive environment (Collis and Montgomery, 1995). RBT involves unit based examination; however, in retailing the external environment involves the channel/supply chain members. In this regard, the RBT view has only limited explanation in terms of relationship mechanism along the channel.

Because there exists a certain structure and relationship mechanism among marketing channel members, theories which emphasizing the role of multiple channel members to succeed in the market, are in particular agency theory and network theory. Agency theory focuses on situations in which the principal gives the right or initiative to act on its behalf; in this sense, the agent acts on behalf of the principal (Eisenhardt, 1989). In retailing, the customer principal aims, to access products/services in various channels; however, the retailer (agent) is responsible for balancing customer service and desired profit level.

In addition to agency theory, network theory also explains the roles of marketing channel members. Network theory takes into account weak and strong ties, and their interaction, where stronger ties enable greater reliability and flexibility (Ketchen et al., 2007). Regarding the theoretical viewpoint, it is important to understand the role of resources, capabilities, relationship management and linkages among channel/chain members when dealing with business issues. The posits of RBT, network and agency theory can be used by channel/supply chain members to reduce the problems of cannibalization.

The word "cannibalism" stands for retailers' interest that can create substitution effects among the departments, brands, brand lines and products (Bultez et. al. 1989). Cannibalism in a company occurs when sales of its products reduces the sales of its others (Traylor, 1986). The firms should provide a novel offering without replacing or implementing other channels (Wolk and Skiera, 2009). Whether cannibalization or synergy occurs is likely to depend on retailers' channel combination capability (Cao and $\mathrm{Li}, 2015)$.

A necessary preliminary step to measuring cannibalization is to create an accurate classification of the entire range of products according to their distinctive features (Kong, 2015). Adding a new channel can threaten sales in existing channels, and lead to differences in prices and margins within channels (Zhang et al., 2010). For instance, intertype competition occurs between different types of retailers selling similar merchandise, when two similarly placed channels lack adequate product and/or service differentiation (Deleersnyder et. al., 2002). Different channels can also cannibalize one another, and it is difficult to foresee outcomes in such circumstances (Avery et al., 2013). Moreover, the location and number of stores need to be analyzed to overcome the negative impact of cannibalization (Sapaj, 2013). Market driving retailers such as United States' Starbucks and Sam's Clubs, Sweden's Hennes and Mauritz, and Italy's Benneton deliberately cannibalize their own stores 
to some extent, through adding new outlets near to successful existing locations, thereby reducing the number of vacant spaces available for potential competitors. Keeping the cannibals in the retailer format is their common preference (Kumar et al., 2000).

Cannibalization has a strong interaction with the success of line extension (Nijjsen, 1999). Line extensions are likely to exhibit greater fit, and hence may lead to greater cannibalization (Lane and Jacobson, 1995). Multiproduct firms need to take into account the cannibalization problem in designing their product lines (Desai, 2001). Incremental sales generated by line extensions are likely to compensate for the loss in sales due to cannibalization (Reddy et. al, 1994). Brand extensions are likely to cannibalize the firm's other products more than the newly branded products (Buday 1989).

Cannibalism mainly results from the similarity between new and existing products in already established markets (Copulsky, 1976). Adding a new product to an existing brand name therefore increases the likelihood of cannibalization (Sharp, 1993). To avoid cannibalization, it is important to ensure that new product releases are as different as possible from existing brands (Sharp, 1993).

The interaction between priceand quality of a brand also plays an important role in the process of cannibalization (Meredith and Maki, 2001). The market share of a company's premium brand is cannibalized by growth in sales of its lower quality brands (Meredith and Maki, 2001). The positioning of a particular private label is decided by the retailer (Gomez-Arias and Bello-Acebron, 2008). National and private brands have been competing with each other for customer acceptance and loyalty for at least seventy-five years (Harvey et al., 1994). There is a high likelihood of cannibalizationwhen many private labels are offered by retailer (Parrish, 2010).

Cannibalization is also likely to occur when the same customers are targeted through different channels (Levy and Weitz, 2001). Many retailers believe that integrating online channel as an additional distribution channel to retailers' traditional distribution system does not generate new sales but rather, cannibalizes sales from existing channels (Kollmann et.al., 2012:186) and creates channel conflicts (Steinfield 2002; Montoya-Weiss et. al., 2003). Internet is cannibalistic by nature, and is likely to replace all conventional ways of doing business (Porter, 2001). Adding internet channel impacts long run performance of firm's existing channel structure (Deleersnyder et. al., 2002). Due to cannibalism threat, many companies avoid using the internet as a distribution channel when entering into a new market, or remove their existing internet channel (Gilbert and Bacheldor, 2000). Wal-Mart and Home Depot, being amongst the leading mega retailers, discourage Black \& Decker from selling its products through the internet (Lee et. al, 2003). Another outcome of online channel usage is internet disintermediation. Internet disintermediation impacts various industries (Garven, 2002). For instance, sales agents acting as retailers in the insurance industry, perceive cannibalization as a negative driver for their effort, job satisfaction and performance (Sharma et al., 2010). 
Ward and Morganosky (2000) examine cannibalization between traditional retail store channels and online channels among variety of products within different product categories. It is revealed that customers who search for product information online positively impact retail store purchases. However, searching for product information in physical stores do not impact online purchases. This finding is also empirically supported by Verhoef et.al (2005), who measure various channels differential "lock-in" (a channel's ability to get sales following product search in that channel) rates finding higher rates for physical stores compared to online web sites. As highlighted in Global Survey of Online shoppers, most consumers who search for information online purchase in an offline channel (PWC, 2015).

Kollmanet. al (2012) empirically analyze shopping motives, cannibalization and synergetic effects between online-offline multichannel systems. When customers' convenience orientation increase, their selection for the online channel over the offline channel is positively impacted. Different service levels across channels throughout purchasing processes provide background for channel synergies.

Some studies emphasize that cannibalization rarely affects to the existing channel by replacing or reducing its importance (Deleersnyder et. al., 2002). In various studies that examine the impact of retail store additions on the existing channel, there have been conflicting implications, due mainly to the different methodologies and retailer types considered in the analyses (Pauwels and Neslin, 2015). This diversity of approaches has also lead to controversial results in research on cannibalization. Some research assumes no overlap between consumers of new and remanufactured products, and therefore, that cannibalization does not exist. On the other hand, according to Guide and Li (2010), partial cannibalization occurs, and remanufactured products compete with new products in terms of price. Traylor (1986) reveals that while cannibalism is rarely desirable, and can be regarded as positive if it increases the market value of the firm by stabilizing earnings, or if the cannibalizing product attracts new customers who otherwise might prefer a competing product. Moreover, only a minimal impact on cannibalization is caused by adding an online channel to an existing channel, as the internet channel does not necessarily lead to the cannibalization of offline sales (Deleersnyder et. al., 2002; Dholakia et al., 2005).

However, cannibalization is acknowledged as inevitable, and to some extent, favorable (Ivanov, 2007).The effects of the specific investments and the different requirements not only have a direct impacton cannibalization, but the relationship is mediated by the willingness to cannibalize (Mols, 2001). The remarkable integration of the firm's different marketing channels can prevail over these problems, and simultaneously, generate higher multi-channel performance (Brown andDant, 2014). 


\section{CONCEPTUAL FRAMEWORK AND RESEARCH PROPOSITIONS}

The field of retailing combines Business to Business (B2B) and Business to Consumer (B2C) (Dant and Brown, 2008). However, the viewpoint of marketing channels serve as the "last mile" of the supply chain, focusing on the satisfaction of end customers' needs (Kozlenkova et al., 2015). Therefore, in addition to the marketing perspective, an understanding of the supply chain is valuable in addressing issues such as cannibalization.

Marketing activities such as catalogs, direct mail promotions and media advertising contribute significantly to revenues. They support to have revenues not only from sales through the new channel but also by creating interactions across different channels (Pauwelsand Neslin, 2015). The marketing function is a main driver for managing various significant linkages and relationships between the stakeholders (Moorman and Rust, 1999). The growth of e-commerce has altered business models, impacting on all aspects of the marketing mix (Webb, 2002). Product promotion, new sales channels, direct savings, decreased cycle time and enhanced customer service are among the main effects of electronic commerce on marketing (Gunasekaran et al., 2002).

Retailers are important players in the marketing channel, assuming not only marketing leadership, but also the leadership of the supply chain through its management. Supply chain is a network of organizations involved in upstream and downstream linkages with different processes and activities that produce value in the form of goods and services for end- customers (Christopher, 1992). The main purpose of supply chain management is to provide strategic assets, such efficiency in related supply chain activities, and short order cycle time (Skjoett-Larsen, 1999). In retail supply chains the retailer generally acts as the leading company (Yumurtac1, 2011).According to the supply chain perspective, supply chain members are dependent on each other for managing relationships and creating value.

As B2B and B2C are both in cooperated within the field of retailing (Dant and Brown, 2008), marketing and supply chain related constructs are discussed in order to conceptualize the research propositions.

When cannibalization is experienced by the retailers, addressing and overcoming the issue require many marketing and/or supply chain activities/decisions to be taken into consideration. A priori propositions are formed in line with the literature review on marketing, multichannel marketingstrategy, supply chain and cannibalization. Marketing perspective, supply chain perspective and marketing/supply chain interfaces are provided to state the solid background for each proposition.

It should be noted that all propositions are based on the following these assumptions firstly, cannibalization occurs and negatively impacts the retailer, secondly, the retailer has a multichannel marketing channel strategy (online and offline), thirdly the retailer has marketing and supply chain orientation/capability, and lastly takes a holistic management view of its departments. 
Thus, the following research propositions to overcome cannibalization with the afore mentioned perspectives (to reduce the effects of cannibalization) are stated; and herein the conceptual framework is presented.

\subsection{Marketing Perspective}

\section{Store Sales}

Multichannel operations are likely to enhance sales by increasing their share of customers' wallets (Zhang et al., 2010). A retailer focuses on how customer online preferences, as shown by its website data, impact off-line sales (Biyalogorsky and Naik, 2003). Multiple channel strategy is oriented to customers, and aims to enhance customer loyalty (Wallace et al., 2004; Payne and Frow, 2005). Store sales are examined in terms of a marketing mix approach, which enables understanding of store substitution and channel behavior (Popkowski-Leszczyc and Timmermans, 1997).

According to marketing perspective, cannibalization refers to reduction in a company's sales volume, sales revenue, or market share of products as a result of the introduction of a new product by the company itself (Goodchild, 1984).

Proposition 1: When cannibalization is experienced, the adjustment of sales levels across multiple channels falls under the responsibility of the marketing function.

\section{Customer Loyalty}

Channel performance is determined in accordance with the existing customers' inherent loyalty in a certain channel and the channel's attractiveness for switching customers (Gensler et al., 2007). Efficient customer management allows the identification of the most profitable customer flows among multiple channels, and assists in the identification of opportunities to switch customers across channels (Vanheems and Kelly, 2009). Firms which use multichannel marketing require advanced information management technologies to enable customer switching between channels (Rangaswamy and Bruggen, 2005).

The coordination of multiple channels is likely to build consumer trust, enhance loyalty and provide cross-selling advantage (Cao and $\mathrm{Li}, 2015$ ). Marketing activities mainly serve for developing,maintaining or increasing customers' loyalty (Dick and Basu, 1994).

Proposition 2: When cannibalization is experienced, ensuring the desired customer loyalty across multiple channels falls under the responsibility of the marketing function. 


\section{Assortment}

The level of assortment is determined in accordance with inventory management decisions in each channel (Burt and Sparks, 2003). The first stage in optimizing the product assortment in stores is often considered to be the demand forecast (Kong, 2015). Assortment choice plays vital role in retail marketing (Bolderston, 1956). The customer chooses a channel based on breadth and depth of assortment (Zhang et al., 2010). Customers' preferences are impacted by the assortment strategies, where low quality products is likely to cannibalize sales of high quality products (Desai, 2001). A common assumption in marketing is based on the concept that greater assortment brings benefits to customers (Chernev, 2003).

Proposition 3:When cannibalization is experienced, assortment decisions across multiple channels fall under the responsibility of the marketing function.

\section{Integrated Marketing Communication}

The marketing communication system is an important instrument in the promotion of products and services (Oluç, 2006). The elements of the promotional mix are coordinated with integrated marketing communication (IMC) in a unified communication (Boone and Kurtz, 2007). IMC comprises of advertising, public relations, sponsorship, sales promotion, merchandising, personal selling, direct marketing communications, packaging, exhibitions and trade shows (Pickton and Broderick, 2004). The ideas and elements of IMCs are applicable for retail marketing (Nowak et al., 1996). The starting point for developing an integrated multi-channel marketing channel strategy is understanding the level of e-commerce utilization(Brown and Dant, 2014). Understanding the synergy between electronic commerce and traditional brick-and-mortar channels is vital to ensuring the optimal utilization of each channel (Vasile and Teodorescu, 2015). The greater the seamlessness of the experience to the customers through integrated multiple channels, the higher the level of performance achieved (Brown and Dant, 2014). IMC is also helpful for creating seamless customer experience.

Proposition 4:When cannibalization is experienced, redesigning integrated communication on behalf of multiple channels falls under the responsibility of the marketing function

\subsection{Marketing and Supply Chain Interfaces}

\section{Customer Relationship Management}

Retailers aim to benefit from relationships with customers (Anderson et al., 2007) by employing customer relationship management (CRM), a holistic approach to creating stakeholder value (Payne and Frow, 2005). The establishment of long-term relationships with stakeholders, including customers, suppliers, employees and competitors, is a key instrument for increasing competitiveness (Hunt, 
2002). CRM is amongst the most crucial supply chain processes (Cooper and Lambert, 2000). CRM takes a company-wide approach; however, it needs to be carefully coordinated (Ryals and Knox, 2001). Successful supply chain management requires cross-functional integration, in which marketingplays an essential role (Lambert and Cooper , 2000). Therefore, CRM bridges the divide between marketing and the supply chain to reduce the likelihood of cannibalization. The key components of the channel are the inherent customer loyalty to a particular channel, and the channel's capability to attract customers from other channels (Gensler et al., 2007). Customers today have an increased range of channel options. Managing customer relationships effectively within a multichannel environment is at the heart of successful CRM (Payne and Frow, 2004).

CRM provides information to coordinate all of the business processes that deal with customers to identify, attract and retain most profitable customers (Laudon and Laudon, 2013) both in B2B and $\mathrm{B} 2 \mathrm{C}$ retail marketing.

Proposition 5:When cannibalization is experienced, planning customer relationship management practices in multiple channels becomes the responsibility of both the marketing and supply chain functions.

\section{Store Selection\&Location Decision}

In multiple channel strategy, store selection and location decisions are made in the interest of both customers and supply chain members (Miller et al., 2006). Store selection and location decision comprise many criteria from marketing and supply chain management such as accessibility of location and transportation, customer traffic, customer purchasing habits and price (Erbiylk et.al, 2012). To measure cannibalization, it is necessary to explore the interactions between variations in size and the overall number of stores (Sapaj, 2013). The careful selection of new store locations is crucial to minimizing cannibalization of sales in existing stores (Kelly et al., 1993). Cannibalization occurs when the new store location acts as a competitor to the original store, and draws customers away from it (Kelly et al., 1993).

Proposition 6: When cannibalization is experienced, changing store selection and location decisions across multiple channels accord with both the marketing and supply chain functions.

\section{Pricing}

The number of intermediaries in the marketing channel impact the prices of the products (Matsuda et al., 1997). Customers expect pricing consistency across channels (Levy and Weitz, 2012). Pricing strategies are influenced by the dominance of multichannel retailing (Tang and Xing, 2001). Similarities among products sold in the physical retail store and on price-based substitution fronts 
leads to cannibalization in retailing (Kong, 2015). Increasing competition and consumer awareness compel retailers simultaneously to increase revenues and decrease operating costs. Therefore, it becomes crucial for retailers to have a clear understanding of the different aspects of the retail supply chain, and of how various components of the chain can be integrated (Bhattacharjee and Ramesh, 2000). To overcome cannibalization, the seller could lower the quality of the low-end model, allowing it to reduce the price of the high-end (Moorthy and Png, 1992).Price elasticity exists when price changes are made possible either by the introduction of a new product, or a change in the existing product, by variations in the process, logistics and marketing strategy (Raghavan, 2005). Regarding this, retailers need to take multiple perspectives on pricing (Bhattacharjee and Ramesh, 2000). Pricing strategies should be coordinated with the marketing and supply chain efforts to provide affordable prices for the customers across all retail formats.

Proposition 7: The adjustment of price levels in multiple channels fall under the responsibility of both the marketing and supply chain functions.

\subsection{Supply Chain Perspective}

\section{Coordination \& Control}

A coordination mechanism is a set of methods used to manage interdependence between organizations (Guide and $\mathrm{Li}, 2010$ ). Coordination and control are facilitated through information sharing (Lee and Whang, 2000). Information sharing involves members of the supply chain sharing demand information and forecasts, inventory status, capacity and promotion plans, production schedules, and shipment schedules information (Lee et al., 2000). Issues of coordination between traditional and internet supply chains play significant roles in supply chain management (Cattani et. al., 2004). Lack of transparency in supply chain management is a barrier to effective coordination among supply chain members (Kanda and Deshmukh, 2008).

Coordination and control policies are specified for the channel to overcome cannibalization (Raza et al., 2011). The Internet allows for a channel in competition with retailers' traditional distribution channels, and therefore, any retailer transacting business on-line needs to overcome the issues of on-line activities cannibalizing in physical store operations, and ensure coordination of the Internet with physical channels, namely, in multiple channels (Biyalogorsky and Naik, 2003).

Proposition 8: When cannibalization is experienced in multiple channels, coordination \& control mechanisms for information sharing among supply chain members become the responsibility of the supply chain functions. 


\section{Visibility}

Visibility is a potential outcome of information sharing in supply chain management (Barratt and Oke, 2007). End-to-end visibility enables transparency in supply chains, allowing accessibility to the necessary information any member at any time (Christopher and Lee, 2004). The goals of retailers' primary supply chain management are to achieve greater visibility for the chain, maximize asset utilization, enhance internal goal alignment, and streamline the inventory across the network (Randall et al., 2011).

Proposition 9: When cannibalization is experienced in multiple channels, providing the desired level of visibility among supply chain members becomes the responsibility of the supply chain functions.

\section{Power Dependence}

The channel leader is usually the most powerful member in the channel and uses its power to manage the planning processes (Weitz and Jap, 1995). Controlling other channel members arises from an imbalance in resources, hence the more powerful channel member has greater resources that are highly valued by the less powerful channel member (Weitz and Jap, 1995).

For each type of dependency, there are many coordination mechanisms available $\mathrm{Xu}$ and Beamon, 2006). The producer dependence on the retailer is amongst the main driver in supply chain management to overcome cannibalization (Oubina et al., 2006). Different network structures to different interdependencies for each kind of supply chain network structure exist to reduce the impact of cannibalization (Nassimbeni, 1998).

Proposition 10: When cannibalization is experienced, in multiple channels, power dependence issue among supply chain members falls under the responsibility of the supply chain functions.

\section{Inventory Management and Merchandise Planning}

Given that retailers are forced to carry increasingly broad portfolios, they need to take into account the impact of cannibalization and demand substitution (Shah and Avittathur, 2007). Decisions on channel design have an impact on sourcing and inventory management issues, such that sharing forecasting and inventory levels are two activities associated with supply chain management (Fliedner, 2003). Inventory management plays a key role in retailing, both in physical and online channels (Agatz et al., 2008), as merchandise must be replenished in a responsive manner in any channel (Tan, 2001). Inventory management and merchandise planning are supported by right demand forecasting models among supply chain members, helping to reduce cannibalization effect (Kong, 2015). 
Proposition 11: When cannibalization is experienced in multiple channels, inventory management \& merchandise planning are in accord with the supply chain function, entailing the participation of various supply chain members.

Figure 1. Conceptual Framework to Overcome Cannibalization through Marketing and Supply Chain Perspective

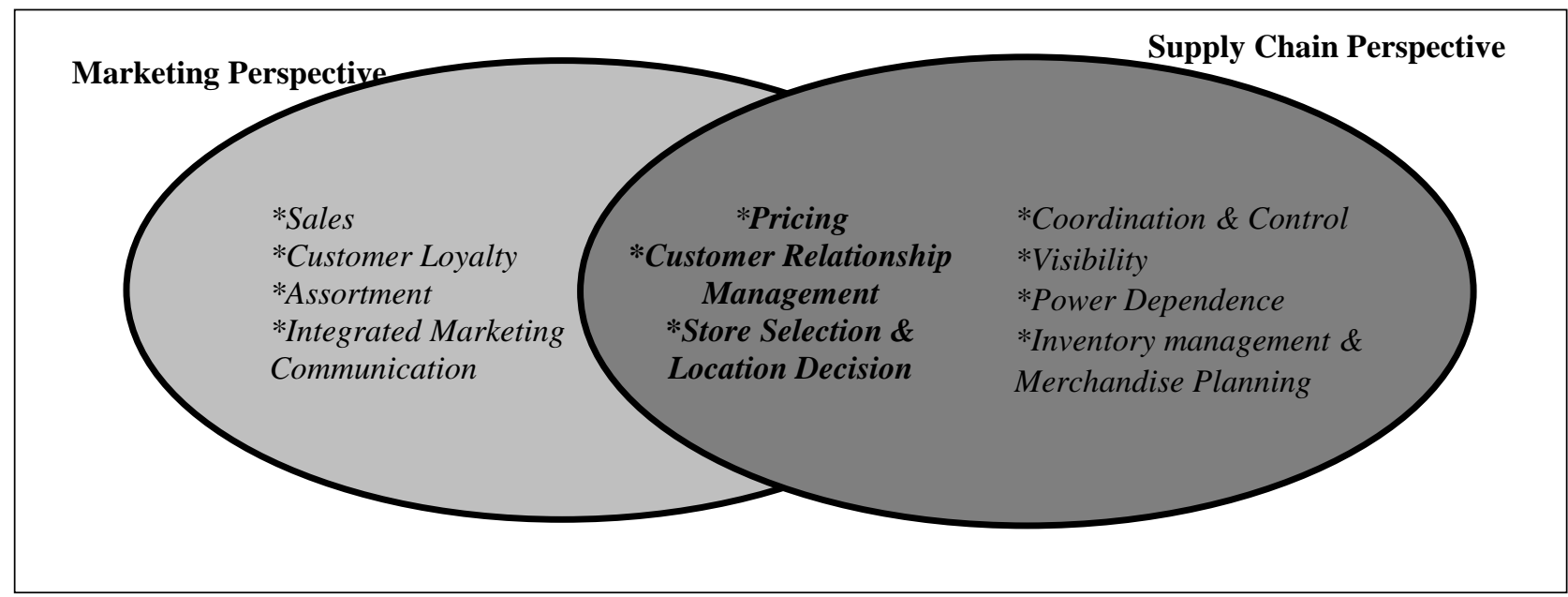

* denotes activities/issues/decisions to overcome cannibalization

In line with our propositions, Figure 1 shows that both the marketing and the supply chain perspective are needed to overcome cannibalization to manage multiple channel strategy.

The channels of retailers are amongst the main resources that drive sales, integrated marketing communication, customer loyalty and assortment. On the other hand, it is more likely that operational benefits will be achieved by operating multiple channels, in this case, coordination \& control, visibility, power dependence, inventory management $\&$ merchandise planning. Both marketing and supply chain perspective should serve for enhancing channel performance.

To minimize cannibalization, companies need to ensure that their new brand entries address different market niches, preferably ones that are either unfilled, or that are currently satisfied by competitors (Kim and Lavack, 1996).

\section{CONCLUSION AND FURTHER RESEARCH}

Regarding integrated management structure of multiple channels, holistic evaluation is necessary to overcome the issue of cannibalization. Currently, the retailing industry is growing not only in emerging economies, but also in developed economies, creating an increasing demand for marketing and supply chain perspectives, and the need for a more comprehensive focus on managerial issues. Therefore, from a practical perspective, our framework provides management guidelines for reducing the impact of cannibalization. Moreover, retailers should focus on the differentiations between multiple channel and cross-channel strategy. 
As discussed in the previous sections, the proposed conceptual model in this study combines supply chain and marketing perspectives in order to overcome cannibalization in retailing. It also considers the intersections of marketing and supply chain perspectives regarding activities, issues and decisions. Based on the literature review of the area of cannibalization, the marketing function has the responsibility of overcoming the negative impact of cannibalization relates through the adjustment of sales levels, providing the desired customer loyalty, selecting the assortment and redesigning integrated marketing communication in multiple channels. The marketing and supply chain functions, on the other hand, are responsible for planning customer relationship management, changing store selection and location decisions, and adjusting price levels among the channels. Last but not least, the supply chain function in overcoming cannibalization is to arrange coordination \& control mechanisms, provide the desired level of visibility, create a balance in power dependence, and take responsibility for inventory management \& merchandise planning among supply chain members in multiple channels. Empirical evidence will be valuable in supporting the propositions of the conceptual model.

Further research can be conducted with different retailer formats in different geographical regions through research methods such as in-depth interviews and focus group studies. Moreover, the identification of key performance indicators to determine on whether or not cannibalization exists will be beneficial for professionals. In addition to these, longitudinal research is likely to reveal how retailers adopt to changing dynamics in retailing. Besides retailers, survey method can be used to reveal consumer perceptions on the multiple channel strategy, and whether they regard cannibalization as a problem.

\section{REFERENCES}

Agatz, N. A. H., Fleischmann, M. and Jo, A. E. E. van Nunen (2008). "E-fulfillment and multichannel distribution- a review", European Journal of Operations Research, 187: 339-356.

Anderson, J., Jolly, L., and Fairhurst, A. (2007). "Customer relationship management in retailing: A content analysis of retail trade journals", Journal of Retailing and Consumer Services, 14(6):394-399.

ATKearney (2014). "On solid ground: brick and mortar is the foundation of omnichannel retailing", Report.

Avery, J., Steenburgh, J. T., Deighton, J. and Caravella, M. (2012). "Adding bricks to clicks: predicting the patterns of cross-channel elasticities over time", Journal of Marketing, 76(3): 96111. 
Avery, J., Steenburgh, T. J., Deighton, J., and Caravella, M. (2013). "Adding Bricks to Clicks: On the Role of Physical Stores in a World of Online Shopping”, GfK Marketing Intelligence Review, 5(2): 28-33.

Barratt, M., and Oke, A. (2007). "Antecedents of supply chain visibility in retail supply chains: a resource-based theory perspective", Journal of Operations Management, 25 (6): 1217-1233.

Bhattacharjee, S., and Ramesh, R. (2000). A multi-period profit maximizing model for retail supply chain management: an integration of demand and supply-side mechanisms. European journal of operational research, 122(3), 584-601.

Biyalogorsky, E. and Naik, P. (2003). "Clicks and mortar: the effect of online activities on offline sales. Marketing Letters”, 14(1): 21-32.

Balderston, F. E. (1956). "Assortment choice in wholesale and retail marketing", The Journal of Marketing, 175-183.

Boone, L. E. and Kurtz, D. L. (2007). "Contemporary marketing", Mason: OH: Thomson/SouthWestern.

Brown, J. R., and Dant, R. P. (2014). "The Role of e-Commerce in Multi-Channel Marketing Strategy". In Handbook of Strategic e-Business Management, Springer Berlin Heidelberg.

Buday, T. (1989). “Capitalizing on brand extensions. Journal of Consumer Marketing”, 6(4): 27-30.

Bultez, A., Gijsbrechts, E., Naert, P. and VandenAbeele, P. (1989). "Asymmetric cannibalism in retail assortments", Journal of Retailing, 66 (Summer):153-192.

Burt, S. L. and Sparks, L. (2003). "Power and competition in the UK retail grocery market", British Journal of Management, 14(3): 237-254.

Cao, L. and Li, L. (2015). “The impact of cross-channel integration on retailers' sales growth”, Journal of Retailing, 91(2):198-216.

Cattani, K. D., Gilland, W. G., and Swaminathan, J. M. (2004). "Coordinating traditional and internet supply chains", In Handbook of Quantitative Supply Chain Analysis (pp. 643-677). Springer US.

Chernev, A. (2003). When more is less and less is more: The role of ideal point availability and assortment in consumer choice. Journal of consumer Research, 30(2), 170-183.

Christopher, M. L. (1992). "Logistics and Supply Chain Management”, London: Pitman Publishing.

Christopher, M., and Lee, H. (2004). "Mitigating supply chain risk through improved confidence", International Journal of Physical Distribution \& Logistics Management, 34(5): 388-396. 
Collins, D. J. and Mongomery, C. A, (1995). "Competing on resources: strategy in the 1990s", Harvard Business Review, 73 (4): 118-128.

Cooper, M. C., Lambert, D. M., and Pagh, J. D. (1997). "Supply chain management: more than a new name for logistics", The International Journal of Logistics Management, 8(1): 1-14.

Copulsky, W. (1976). "Cannibalism in the Marketplace”, The Journal of Marketing, 103-105.

Dant, R. P. and Brown, J. R. (2008). "Bridging the B2C and B2B research divide: the domain of retailing literature", Journal of Retailing, 84(4):371-397.

Deleersnyder, B., Geyskens, I., Gielens, K. and Dekimpe, M. G. (2002). "How cannibalistic is the internet channel?",International Journal of Research in Marketing, 19 (4): 337-348.

Deloitte, (2014). "Global Powers

Retailing”.http://www2.deloitte.com/content/dam/Deloitte/global/Documents/ConsumerBusiness/dttl-CB-GPR14STORES.pdf. (10.08.2015).

Desai, P. S. (2001). "Quality segmentation in spatial markets: When does cannibalization affect product line design?", Marketing Science, 20(3):265-283.

Dick, A. S., \&Basu, K. (1994). Customer loyalty: toward an integrated conceptual framework. Journal of the academy of marketing science, 22(2), 99-113.

Dholakia R. R., Zhao, M. and Dholakia, N. (2005). "Multichannel Retailing: A Case Study of Early Experiences", Journal of Interactive Marketing, 19(2): 63-74.

Ehrens S and Zapf S. (1999). "The Internet business-to-business report", New York (NY): Bear, Stearns \& Co. Inc.

Eisenhardt, K. (1989). “Agency theory: An assessment and review", Academy of Management Review, 14(1): 57-74.

E-Marketer, (2014). "Global B2C ecommerce sales to hit \$1.5 Trillion this year driven by growth in emerging markets". http://www.emarketer.com/Article/Global-B2C-Ecommerce-Sales-Hit-15Trillion-This-Year-Driven-by-Growth-Emerging-Markets/1010575.(04.05.2015).

Erbıyık, H., Özcan, S., and Karaboğa, K. (2012). "Retail store location selection problem with multiple analytical hierarchy process of decision making an application in Turkey. ProcediaSocial and Behavioral Sciences", 58(2012): 1405-1414.

Fliedner, G. (2003). "CPFR: an emerging supply chain tool. Industrial Management \& Data Systems", 103(1): 14-21.

Frazier, G.(1999). "Organizing and managing channels of distribution. Journal of the Academy of Marketing Science”, 27 (Spring), 226-240. 
Garven, J. R. (2002). "On the implications of the internet for insurance markets and institutions", Risk Management and Insurance Review, 5(2):105-116.

Gensler, S., Dekimpe, M. G. and Skiera, B. (2007).“Evaluating channel performance in multi-channel environments", Journal of Retailing and Consumer Services, 14 (1): 17-23.

George, M., Kumar, V. and Grewal, D., (2013). "Maximizing profits for a multi-category catalog retailer", Journal of Retailing, 89(4): 374-396.

Geyskens, I., Gielens, K. and Dekimpe, M. G. (2002). "The market valuation of Internet channel additions", Journal of Marketing, 66 (2):102-119.

Gilbert, A. and Bacheldor, B., (2000). “The big squeeze",Informationweek, March(27): 47-56.

Goodchild, M. F. (1984). "ILACS: a location-allocation model for retail site selection", Journal of Retailing, 60:84-100.

Guide Jr, V. D. R., and Li, J. (2010). "The potential for cannibalization of new products sales by remanufactured products", Decision Sciences, 41(3): 547-572.

Gunasekaran, A., Marrib, H. B., McGaugheyc, R. E. and Nebhwanib, M. D. (2002). "E-commerce and its impact on operations management", International Journal of Production Economics, 75 (2002): 185-197.

Harvey, M., Rothe, J. T., and Lucas, L. A. (1998). "The" trade dress" controversy: A case of strategic cross-brand cannibalization", Journal of Marketing Theory and Practice, 1-15.

Hunt, S. D. (2002). "Foundations of Marketing Theory: Toward a General Theory of Marketing", M.E. Sharpe, Armonk, NY.

ICT Facts and Figures - "The world in 2015". http://www.itu.int/en/ITUD/Statistics/Pages/facts/default.aspx. (10.08.2015).

Ivanov, S. (2007). "Conceptualizing cannibalization: the case of tourist companies", S Ivanov, Yearbook of International University College, 20-36.

Kanda, A., and Deshmukh, S. G. (2008). "Supply chain coordination: perspectives, empirical studies and research directions", International Journal of Production Economics, 115(2): 316-335.

Kelly, J. P., Freeman, D. C.,andEmlen, J. M. (1993). "Competitive impact model for site selection: the impact of competition, sales generators and own store cannibalization", International Review of Retail, Distribution and Consumer Research, 3(3): 237-259.

Ketchen, D. J., Ireland, R. D. and Snow, C. C. (2007). "Strategic entrepreneurship, collaborative innovation, and wealth creation", Strategic Entrepreneurship Journal, 1(3-4): 371-385. 
Kilcourse, B. and Rowen, S. (2008). "Finding the integrated multi-channel retailer", Retail Systems Research, Benchmark Study.

Kim, C. K.andLavack, A. M. (1996). "Vertical brand extensions: current research and managerial implications", Journal of Product \& Brand Management, 5(6): 24 - 37.

Kollmann, T., Kuckertz, A. and Kayser, I. (2012). "Cannibalization or synergy? Consumers' channel selection in online-offline multichannel systems", Journal of Retailing and Consumer Services, 19(2): 186-194.

Kong, E. L. (2015). "Cannibalization effects of products in Zara's stores and demand forecasting", PhD diss., Massachusetts Institute of Technology.

Kozlenkova, I. V., Hult, G. T., Lund, D. J., Mena, J. A. and Kekec, P. (2015). "The Role of Marketing Channels in Supply Chain Management", Journal of Retailing, (article in press).

Kumar, N., Scheer, L. K. And Steenkamp, J- B. E. M. (1995). "The effects of perceived interdependence on dealer attitudes", Journal of Marketing Research, 32(August): 348-56.

Kumar, N., Scheer, L., and Kotler, P. (2000). "From market driven to market driving", European Management Journal, 18(2): 129-142.

Lambert, D. M., \& Cooper, M. C. (2000). Issues in supply chain management. Industrial marketing management, 29(1), 65-83.

Lane, V., and Jacobson, R. (1995). "Stock market reactions to brand extension announcements: The effects of brand attitude and familiarity", The Journal of Marketing, 63-77.

Laudon, K. C. and Laudon, J. P. (2013). "Management information systems: managing the digital firm", Pearson Education.

Lee, H. L. and S. Whang (2000). "Information sharing in a supply chain". International Journal of Technology Management”, 20(3/4): 373-387.

Lee, H. L., So, K. C., andTang, C. S. (2000). The value of information sharing in a two-level supply chain. Management science, 46(5), 626-643.

Lee, Y., Lee, Z. and Larsen, K. R. T. (2003). "Coping with internet channel conflict Communication of ACM", 46(7): 137-142.

Levy, M. and Weitz, B. (2012). "Retailing management”,New York:McGraw-Hill.

Levy, M., and Weitz, B. A. (2001). "Retailing management”, New York: McGraw-Hill.

Mahoney, J. T. (1995). "The management of resources and the resource of management", Journal of Business Research, 33(2): 91-101. 
Matsuda, T., Clark, T. H., \& Lee, H. G. (1997, January). Electronic commerce for agricultural transactions: role of intermediaries and accurate pricing. In System Sciences, 1997, Proceedings of the Thirtieth Hawaii International Conference on (Vol. 4, pp. 13-20). IEEE.

Mentzer, J. T., DeWitt, W., Keebler, J. S., Min, S., Nix, N. W., Smith, C. D., and Zacharia, Z. G. (2001). "Defining supply chain management", Journal of Business Logistics, 22(2), 1-25.

Meredith, L., and Maki, D. (2001). "Product cannibalization and the role of prices", Applied Economics, 33(14): 1785-1793.

Miller, F., Mangold, W. G., \& Holmes, T. (2006). "Integrating geographic information systems (GIS) applications into business courses using online business geographics modules", Journal of Education for Business, 82(2), 74-79.

Mols, N. P. (2001). "Organizing for the effective introduction of new distribution channels in retail banking”, European Journal of Marketing, 35(5/6): 661-686.

Montoya-Weiss, M. M., Voss, G.B. and Grewal, D. (2003). "Determinants of online channel use and overall satisfaction with a relational, multichannel service provider", Journal of the Academy of Marketing Science, 31(4): 448-458.

Moorman, C. and Rust, R. T. (1999). "The role of marketing”, Journal of Marketing, 63(special issue): 180-197.

Moorthy, K. S., and Png, I. P. (1992). "Market segmentation, cannibalization, and the timing of product introductions", Management Science, 38(3):345-359.

Narwal, and Sachdeva, (2013). "Impact of information technology (IT) on consumer purchase behavior", Journal of Arts, Science \& Commerce, 4(3):41-53.

Nassimbeni, G. (1998). "Network structures and co-ordination mechanisms: a taxonomy. International Journal of Operations \& Production Management, 18(6):538-554.

Neslin, S. A., and Shankar, V. (2009). "Key issues in multichannel customer management: current knowledge and future directions", Journal of Interactive Marketing, 23(1):70-81.

Nijssen, E. J. (1999). "Success factors of line extensions of fast-moving consumer goods", European Journal of Marketing, 33(5/6): 450-474.

Nowak, G. J., Cameron, G. T., \& Delorme, D. (1996). Beyond the world of packaged goods: Assessing the relevance of integrated marketing communications for retail and consumer service marketing. Journal of Marketing Communications, 2(3), 173-190.

Oluç, M. (2006). “TemelPazarlamaKavramları”, Beta Publications: İstanbul.

Parrish, E. (2010). "Retailers' use of niche marketing in product development", Journal of Fashion 
Marketing and Management: An International Journal, 14 (4): 546 - 561.

Pauwels, K., and Neslin, S. A. (2015). "Building With Bricks and Mortar: The Revenue Impact of Opening Physical Stores in a Multichannel Environment”, Journal of Retailing, 91(2): 182-197.

Payne, A., and Frow, P. (2004). "The role of multichannel integration in customer relationship management", Industrial Marketing Management, 33(6): 527-538.

Payne, A., and Frow, P. (2005). "A strategic framework for customer relationship management", Journal of Marketing, 69(4): 167-176.

Pfeffer, J. and Salancik, G. R. (1978). "The external control of organizations: a resource dependence perspective", Harper \& Row, New York.

Pickton, D. and Broderick, A. (2004). "Integrated marketing communications", Financial Times Prentice Hall.

Popkowski-Leszczyc, P. and Timmermans, H. (1997). "Store-switching behavior", Marketing Letters, 8(2): 193-204.

Porter, M. E. (2001). “Strategy and the internet”, Harvard Business Review, 79(3): 62-78.

PWC (2015). "Total Retail 2015. Retailers and the Age of Disruption",https://www.pwc.com/gx/en/retail-consumer/retail-consumer-publications/globalmulti-channel-consumer-survey/assets/pdf/total-retail-2015.pdf. (09.10.2015).

Raghavan Srinivasan, S., Ramakrishnan, S., and Grasman, S. E. (2005). "Identifying the effects of cannibalization on the product portfolio", Marketing Intelligence \& planning, 23(4), 359-371.

Randall, W. S., Gibson, B. J., Defee, C. C. and Williams, B. D. (2011). "Retail supply chain management: key priorities and practices", The International Journal of Logistics Management, 22(3):390-402.

Raza, S. A., Al-Kuwari, A. Y., andAloqayli, F. A. A Model for Optimal Pricing and Capacity $\begin{array}{lllll}\text { Allocation } & \text { for } & \text { a } & \text { Firm } & \text { Facing }\end{array}$ Cannibalization.http://www.iieom.org/ieom2011/pdfs/IEOM154.pdf

Reddy, S. K., Holak, S. L., and Bhat, S. (1994). "To extend or not to extend: Success determinants of line extensions", Journal of Marketing Research, 243-262.

Rosenbloom, B. (2007). "Multi-channel strategy in business to business markets: prospects and problems", Industrial Marketing Management, 36 (1): 4-9.

Ryals, L. and Knox, S. (2001). "Cross-functional issues in the implementation of relationship marketing through customer relationship management", European Management Journal, 19(5):534-542. 
Sapaj, S. C. (2013). "Measuring cannibalization in distribution networks: an approach to optimize store locations", Doctoral dissertation, Massachusetts Institute of Technology.

Shah, J.,andAvittathur, B. (2007). "The retailer multi-item inventory problem with demand cannibalization and substitution", International Journal of Production Economics, 106(1): 104114.

Sharp, B. M. (1993). "Managing brand extension. Journal of Consumer Marketing", 10(3): 11-17.

Schramm-Klein, H. (2003). "Multi-channel-retailing”, Wiesbaden.

Sharma, D. and Gassenheimer, J. (2009). "Internet channel's perceived cannibalization: scale development and validation in a personal selling context", European Journal of Marketing. 43 (7/8): 1076-1091.

Sharma, D., Gassenheimer, J. and Alford, B. (2010). "Internet channels and cannibalization: an empirical approach to a sales agent's perspective", Journal of Personal Selling and Sales Management. 30(3): 209-221.

Skjoett-Larsen, T. (1999). "Supply chain management: a new challenge for researchers and managers in logistics", International Journal of Logistics Management, 10(2): 41-53.

Steinfield, C. (2002). "Understanding click and mortar e-commerce approaches: a conceptual framework and research agenda", Journal of Interactive Advertising, 2(2): 1-10.

Tan, K. C. (2001). "A framework of supply chain management literature, European Journal of Purchasing \& Supply Management”, 7(2001): 39-48.

Tang, F. F., and Xing, X. (2001). "Will the growth of multi-channel retailing diminish the pricing efficiency of the web?”,Journal of Retailing, 77(3): 319-333.

Traylor, M. B., (1986). “Cannibalism in multi-brand firms”, Journal of Consumer Marketing, 3(2): 6975.

Gomez-Arias, Tomas J., and Bello-Acebron, L. (2008). "Why do leading brand manufacturers supply private labels?", Journal of Business \& Industrial Marketing, 23(4): 273-278.

Vasile, V., and Teodorescu, I. (2015). "Finding the Synergy when Operating "Bricks and Clicks" Business Models". The Proceedings of the International Conference" Marketing-from Information to Decision", Babes Bolyai University.

Verhoef, P. C. and Donkers, B. (2005). "The effect of acquisition channels on customer loyalty and cross-buying", Journal of Interactive Marketing, 19 (2): 31-43.

Wallace, D. W., Giese, J. L., and Johnson, J. L. (2004). "Customer retailer loyalty in the context of multiple channel strategies", Journal of Retailing, 80(4), 249-263. 
Vanheems, R., and Kelly, J. S. (2009). "Understanding Customer Purchase Switching Behavior When Retailers Use Multiple Channels", International Journal of Integrated Marketing Communications, 1(2).

Ward, M.R., Morganosky, M. (2000). "Online consumer search and purchase in a multiple channel environment", Working Paper, University of Illinois.

Webb, K. L. (2002). "Managing channels of distribution in the age of electronic commerce", Industrial Marketing Management, 31(2): 95-102.

Weitz, B. A., and Jap, S. D. (1995). "Relationship marketing and distribution channels", Journal of the Academy of Marketing Science, 23(4): 305-320.

Wolk, A. and Skiera, B. (2009). "Antecedents and consequences of internet channel performance", Journal of Retailing and Consumer Services, 16(3):163-173.

$\mathrm{Xu}$, L., and Beamon, B. M. (2006). "Supply chain coordination and cooperation mechanisms: an attribute-based approach", Journal of Supply Chain Management, 42(1): 4-12.

Yumurtac1, I. Ö. (2011). "Retail Store Performance Assessment through Supply Chain Perspective", Unpublished PhD Thesis, Izmir University of Economics, Graduate School of Social Sciences, Izmir.

Zhang, J., Farris, P. W., Irvin, J. W.,Kushwaha, T., Steenburgh, T. J., and Weitz, B. (2010). “Crafting integrated multichannel retailing strategies”, Working Paper 09-125, January, 2010. 